\title{
PENAHANAN IJAZAH ASLI PEKERJA DALAM HUBUNGAN KERJA SEBAGAI BAGIAN KEBEBASAN BERKONTRAK
}

\author{
I Wayan Agus Vijayantera \\ Fakultas Hukum Universitas Mahasaraswati \\ E-mail: agus.vije@gmail.com
}

\begin{abstract}
ABSTRAK
Penahanan ijazah asli pekerja dilakukan pengusaha sebagai jaminan pekerja bekerja di perusahaan. Tujuan penulisan adalah untuk mengetahui sumber hukum penahanan ijazah asli pekerja dalam hubungan kerja serta kesepakatan penahanan ijazah asli pekerja sebagai bagian kebebasan berkontrak. Pada pembahasan terkait sumber hukum penahanan terhadap ijazah asli pekerja berdasarkan pada sumber hukum ketenagakerjaan di luar peraturan perundang-undangan karena terdapat kekosongan hukum dalam perundang-undangan ketenagakerjaan. Asas kebebasan berkontrak digunakan sebagai kebebasan dalam menentukan isi perjanjian terutama terkait penahanan ijazah. Pada hakekatnya penahanan ijazah bertentangan dengan Hak Asasi Manusia yakni hak untuk mendapat pekerjaan sehingga mendapatkan penghasilan yang layak. Oleh karena itu perlu peran pemerintah dalam membentuk pengaturan mengenai penahanan ijazah asli pekerja demi mengisi kekosongan hukum.
\end{abstract}

Kata kunci : penahanan, ijazah, kesepakatan, pekerja.

\begin{abstract}
Detention original certificate of workers do employers as guarantee workers are employed at company. The purpose of writing is to know the source of law detention original certificate of workers in employment relationships and agreement of detention original certificate as part of freedom of contract. In the discussion related to legal sources detention against original certificate workers based labor law outside the legislation because there is a legal vacuum in the labor law. The freedom of contract are used as the freedom to determine the content of the agreement especially related the detention of certificate. In essence the certificate detention is contrary to human rights or the right to found a job so get a decent income. Therefore it needs role of government in shaping the regulation concerning the detention of original certificate to fill the legal vacuum.
\end{abstract}

Keywords: detention, certificate, agreements, workers.

\section{Pendahuluan}

Manusia

kehidupannya

dalam

memiliki

kebutuhan-kebutuhan yang harus dipenuhi mulai dari kebutuhan pokok hingga kebutuhan yang timbul dari hasrat untuk memiliki sesuatu benda. Untuk memenuhi kebutuhan-kebutuhan tersebut, maka manusia harus bekerja. 
Seiring berkembangnya zaman, pendidikan saat ini dipandang sebagai syarat untuk bekerja. Untuk dapat bekerja pada perusahaan, seseorang menempuh pendidikan terlebih dahulu untuk mendapatkan ijazah sebagai bukti bahwa dirinya telah menempuh pendidikan.

Berkenaan dengan ijazah bahwa ijazah sebagai benda yang didalamnya melekat hak milik bagi seseorang yang menjadi bukti bahwa orang tersebut telah menempuh pendidikan. Pada dasarnya ketika seseorang melamar pekerjaan pada perusahaan melampirkan fotocopy ijazah dan telah dilegalisir sebagai bukti bahwa ijazah tersebut sama dengan aslinya sehingga bisa digunakan untuk melamar pekerjaan. Pada beberapa perusahaan ada yang menerapkan sistem penahanan terhadap ijazah asli pekerja bagi pekerja yang melamar pekerjaan di perusahaannya baik dengan waktu pengembalian ijazah asli yang ditentukan atau tidak ditentukan oleh pengusaha.

Sistem penahanan ijazah asli ini biasanya dilakukan oleh pengusaha dengan alasan agar pekerja tidak menjadikan perusahaannya sebagai batu loncatan yang mengakibatkan pengusaha kehilangan pekerja yang berdampak pada penurunan kinerja perusahaan. hal ini karena pekerja merupakan komponen yang penting dalam perusahaan karena posisi pekerja sebagai roda penggerak perusahaan. Tanpa ada pekerja maka perusahaan tidak akan dapat beroperasi dalam kegiatan usahanya. Pada sisi lainnya, hal yang dilakukan oleh pengusaha terkait dengan sistem penahanan ijazah asli pekerja dapat dikatakan bertentangan dengan hak seseorang untuk bekerja yang dimaknai bahwa pengusaha menghalangi ketika seseorang tersebut mencari pekerjaan yang layak.

Jika melihat pada ketentuan Undang-Undang Ketenagakerjaan yakni Undang-Undang Republik Indonesia Nomor 13 Tahun 2003 beserta peraturan pelaksanaannya, tidak terdapat peraturan yang mengatur tentang penahanan ijazah asli. Hal ini mengakibatkan adanya kekosongan hukum terkait boleh atau tidaknya dilakukan penahanan ijazah. Akibat kekosongan hukum ini maka pengusaha melakukan penahanan ijazah asli pekerja sebagai syarat diterimanya pekerja untuk bekerja berdasarkan kebiasaan yang terjadi pada dunia kerja serta dengan dasar kebebasan berkontrak.

Cicero pernah mengatakan "ubi societas ibi ius", di mana ada masyarakat di situ ada hukum (Erwin, 2013). Hukum ada di masyarakat guna menciptakan hubungan antara orang yang satu dengan orang yang lain menjadi teratur. Kekosongan hukum yang terjadi terhadap penahanan ijazah asli pekerja perlu adanya pengaturan terkait sehingga dapat menjadi payung hukum demi melindungi hak dan kepentingan pekerja maupun pengusaha agar sama-sama tidak merasa dirugikan 
dalam melaksanakan hubungan kerja, sehingga di sini peran dari pemerintah sangat diharapkan baik dalam membentuk peraturan maupun mengeluarkan kebijakan demi mengisi kekosongan hukum yang terjadi di masyarakat terutama terkait terjadinya tindakan penahanan ijazah asli pekerja.

Berdasarkan hal tersebut maka "Penahanan Ijazah Asli Pekerja Dalam Hubungan Kerja Sebagai Bagian Kebebasan Berkontrak" sangat menarik untuk dikaji terkait dengan permasalahan terkait sumber hukum penahanan ijazah asli pekerja dalam hubungan kerja serta kesepakatan penahanan ijazah asli pekerja sebagai bagian kebebasan berkontrak.

\section{Pembahasan}

\section{Sumber Hukum Penahanan Ijazah Asli Pekerja Dalam Hubungan Kerja}

Hubungan kerja sebagaimana ketentuan Undang-Undang Republik Indonesia Nomor 13 Tahun 2003 tentang Ketenagakerjaan pada Pasal 1 ayat (15) menyatakan bahwa : "Hubungan kerja adalah hubungan antara pengusaha dengan pekerja/buruh berdasarkan perjanjian kerja, yang mempunyai unsur pekerjaan, upah, dan perintah".

Menurut Lanny Ramli, hubungan kerja dikaitkan dengan pelaksanaan pekerjaan atau bekerja mempunyai arti "kegiatankegiatan pengerahan tenaga/jasa seseorang, yaitu pekerja secara terus menerus dalam waktu tertentu dan secara teratur demi kepentingan orang yang memerintahkannya - majikan sesuai dengan perjanjian kerja yang disepakati bersama. Jadi, hubungan kerja adalah pelaksanaan dari perjanjian kerja yang telah dibuat oleh pekerja dan majikan" (Ramli;2008).

Pada dasarnya hubungan kerja tercipta antara pekerja dan pengusaha ketika pekerja mulai diterima untuk bekerja di tempat pengusaha sehingga pekerja tersebut dapat dapat melakukan pekerjaannya sesuai perintah dari pengusaha serta pekerja tersebut mendapatkan hak berupa upah. Jadi hak dan kewajiban yang melekat pada diri pekerja dan pengusaha muncul ketika hubungan kerja tersebut telah terjalin.

Pengaturan mengenai segala hal tentang hubungan kerja antara pekerja dengan pengusaha di Negara Indonesia diatur dalam peraturan perundang-undangan ketenagakerjaan serta beberapa peraturan pelaksanaannya. Peraturan hukum ketenagakerjaan ini sangat penting keberadaannya sebagai payung hukum, namun bila melihat pada peraturan perundang-undangan yang berlaku terkait pengaturan sebelum hubungan kerja tercipta yang berupa proses penerimaan pekerja oleh pengusaha terutama mengenai penahanan ijazah asli pekerja tidak terdapat pengaturannya dalam peraturan perundang-undangan di Indonesia. Hal ini menjadi suatu kekosongan 
hukum terkait pengaturan yang membolehkan atau tidak atas tindakan pengusaha yang melakukan penahanan terhadap ijazah asli pekerja.

Jika kita melihat pada hukum ketenagakerjaan sebagai payung yang melindungi hak pekerja, maka hal ini perlu diatur dalam peraturan hukum sehingga hak pekerja dapat terlindungi secara jelas. Apabila melihat pada tujuan hukum ketenagakerjaan, Menurut Manulang tujuan hukum ketenagakerjaan yakni :

a. Untuk mencapai / melaksanakan keadilan sosial dalam bidang ketenagakerjaan;

b. Untuk melindungi tenaga kerja terhadap kekuasaan yang tidak terbatas dari pengusaha (Khakim, 2014).

Berdasarkan hal tersebut, jelas hukum ketenagakerjaan ini sangat diperlukan sebagai peraturan dalam dunia kerja sehingga dapat memberikan keadilan terkait hak dan kewajiban antara pekerja dan pengusaha, kemudian pula guna memberikan perlindungan bagi pekerja mengingat pengusaha sebagai pemberi kerja memiliki kekuasaan yang lebih sehingga perlu adanya pembatasan agar pengusaha sebagai pemberi kerja tidak semena-mena dalam memperlakukan pekerjanya baik dalam pemberian beban kewajiban maupun pemberian hak pekerja tersebut.

Mengingat bahwa hukum ketenagakerjaan itu sangat penting keberadaannya dalam dunia kerja, maka perlu ditelaah dasar atau sumber hukum yang digunakan pengusaha untuk melakukan penahanan ijazah asli pekerja sehingga dapat diketahui tindakan tersebut bertentangan atau tidak dengan Hak Asasi Manusia ataupun peraturan hukum yang ada. Adapun yang menjadi sumber hukum ketenagakerjaan terdiri dari sumber hukum formal dan sumber hukum materiil. Sumber hukum ketenagakerjaan dalam arti materiil adalah pancasila, sedangkan sumber hukum ketenagakerjaan dalam arti formal terdiri dari sebagai berikut (Ramli, Op.Cit) :

a. Undang-Undang;

b. Peraturan lain;

c. Kebiasaan;

d. Putusan;

e. Perjanjian.

Berdasarkan hal tersebut, ketenagakerjaan tidak hanya bersumber pada peraturan perundang-undangan saja, masih ada sumber lain yang dapat digunakan sebagai sumber hukum ketenagakerjaan. Ditinjau dari segi sumber hukum materiil, pancasila merupakan sumber dari segala hukum sehingga dalam pembentukan hukum maupun kegiatan sehari-hari tidak terlepas dari nilai-nilai pancasila. Nilai yang terkandung pada pancasila tersebut kemudian direfleksikan dalam peraturan berupa UndangUndang Dasar Republik Indonesia. Penahanan ijazah asli milik pekerja oleh pengusaha jika ditinjau dari peraturan Undang-Undang Dasar Republik Indonesia, tindakan tersebut melanggar hak pekerja 
sebagaimana dalam pasal 27 ayat (2) Undang-Undang Dasar yang menyatakan "Tiap-tiap warga negara berhak atas pekerjaan dan penghidupan yang layak bagi kemanusiaan." Maksud dari ketentuan ini demi melindungi hak pekerja untuk mendapat pekerjaan sehingga mendapat penghasilan demi memenuhi kehidupannya secara layak.

Akibat ijazah asli pekerja yang ditahan oleh pengusaha, pekerja tidak bisa untuk mencari kerja di perusahaan lain dengan penghasilan yang lebih layak atau lebih baik demi menunjang kehidupan pekerja tersebut. Hal ini mengingat bahwa ijazah merupakan syarat yang wajib diperlihatkan ketika pekerja melamar pekerjaan di sebuah perusahaan. Oleh karena itu tindakan penahanan ijazah oleh pengusaha tersebut bertentangan dengan Pasal 27 ayat (2) UndangUndang Dasar karena tindakan pengusaha tersebut menghalanghalangi hak pekerja untuk mendapat pekerjaan dengan penghasilan yang layak ataupun memadai dalam menunjang kebutuhan hidupnya.

Pada sumber hukum formil sebagai sumber hukum ketenagakerjaan, pada peraturan perundang-undangan tidak ditemui bahwa tindakan penahanan ijazah tersebut dilarang dalam peraturan perundang-undangan, oleh karena itu perlu dikaji pula pada sumber hukum formil selain peraturan perundang-undangan. Kebiasaan sebagai salah satu sumber hukum formil hukum ketenagakerjaan dapat digunakan sebagai sumber hukum bagi para pihak yakni pekerja dan pengusaha dalam melakukan hubungan hukum yakni hubungan kerja.

Kebiasaan

merupakan perbuatan manusia yang dilakukan berulang-ulang terhadap hal yang sama, bila satu kebiasaan tersebut telah diterima oleh masyarakat dan kebiasaan itu selalu dilakukan berulang-ulang, sehingga tindakan yang berlawanan dengan kebiasaan itu dirasakan sebagai pelanggaran perasaan hukum maka dengan demikian timbullah suatu kebiasaan yang dipandang sebagai hukum (Asikin, et. al. 2008). Kebiasaan yang dilakukan secara berulang-ulang ini menjadi sebuah hukum yang berlaku di masyarakat di luar peraturan perundang-undangan.

Kebiasaan sebagai landasan hukum bagi para pihak dalam membentuk hubungan hukum disepakati melalui perjanjian baik itu perjanjian yang dibuat dalam bentuk tertulis maupun tidak tertulis. Kebiasaan menurut Niewenhus bahwa "kebiasaan bermakna cara atau tingkah laku yang umum diikuti dalam pelaksanaan suatu jenis kontrak tertentu di dalam wilayah atau bidang usaha tertentu. Selanjutnya cara atau tingkah laku tersebut diikuti dalam praktik sebagai kewajiban hukum, tidak menjadi apakah para pihak bermaksud mengikuti kebiasaan tersebut (mengetahui atau tidak mengetahui adanya kebiasaan tersebut)." (Hernoko, 2010). 
Tindakan penahanan ijazah asli milik pekerja yang dilakukan oleh pengusaha tidak terdapat pengaturannya dalam peraturan perundang-undangan, namun tindakan ini didasarkan pada kebiasaan sebagai sumber hukumnya baik kebiasaan yang berlaku dalam dunia kerja pada umumnya di masyarakat maupun kebiasaan yang dilakukan secara berulang-ulang dalam perusahaan sehingga secara tidak langsung kebiasaan tersebut menjadi hukum bagi para pihak.

Kebiasaan yang dilakukan oleh pengusaha dalam melakukan penahanan ijazah asli milik pekerja tersebut selanjutnya timbul kesepakatan antara para pihak yakni pihak pekerja dan pengusaha dengan perjanjian baik perjanjian yang dibuat secara tertulis ataupun secara lisan yang didalamnya mengatur terkait waktu penyerahan ijazah asli oleh pekerja hingga terkait waktu pengembalian ijazah asli tersebut kepada pekerja.

Perjanjian sebagai sumber hukum ketenagakerjaan bersumber pada Undang-Undang maupun kebiasaan. Perjanjian dalam Undang-Undang diatur dalam Kitab Undang-Undang Hukum Perdata. Tindakan penahanan ijazah asli pekerja diperjanjikan oleh pengusaha baik dengan berdasarkan pada kebiasaan maupun berdasarkan peraturan perundang-undangan.

Tindakan penahanan ijazah asli yang dilakukan oleh pengusaha jika dilihat dari sumber hukum berupa kebiasaan maupun perjanjian, maka tindakan tersebut dapat dilakukan oleh pengusaha. Apabila melihat pada rasa kemanusiaan terkait hak asasi yang dimiliki manusia dalam mendapat pekerjaan serta penghidupan layak sebagaimana diatur dalam Undang-Undang Dasar Republik Indonesia, tindakan pengusaha ini merupakan tindakan yang menghalang-halangi pekerjanya untuk mendapat pekerjaan lain di luar perusahaannya yang mampu memberi upah atau penghasilan lebih yang dapat memenuhi kebutuhan hidupnya daripada tempat pekerja bekerja sekarang. Oleh karena itu perlu adanya peraturan hukum secara khusus dalam peraturan perundangundangan ketenagakerjaan yang mengatur terkait penahanan ijazah asli pekerja ini sehingga jelas tindakan yang dilakukan pengusaha tersebut diperbolehkan atau tidak.

Dalam hal terjadi permasalahan terkait penahanan ijazah asli milik perkerja dan permasalahan ini sampai pada upaya penyelesaian litigasi, maka Putusan Pengadilan yang telah mempunyai kekuatan hukum tetap dapat digunakan sebagai dasar atau sumber hukum mengenai boleh atau tidaknya pengusaha melakukan penahanan terhadap ijazah asli milik pekerja dalam menyelenggarakan hubungan kerja. Kesepakatan Penahanan Ijazah
Asli Pekerja Sebagai Bagian
Kebebasan Berkontrak 
Dalam perspektif hukum perdata, Ijazah dikategorikan atau dilihat sebagai sebuah benda yang memiliki nilai atau berharga dan didalamnya melekat hak milik seseorang terhadap benda tersebut. Ijazah dalam hukum perdata termasuk sebagai benda bergerak dan berwujud. Ijazah sebagai benda berwujud karena ijazah sebagai benda yang memiliki wujud fisik sehingga dapat diraba menggunakan panca indra manusia, serta ijazah sebagai benda bergerak karena sifat dari ijazah tersebut dapat berpindah atau dipindahkan.

Ijazah sebagai benda jika dikaitkan dengan tindakan pengusaha yang melakukan penahanan ijazah asli pekerja, terdapat peralihan pihak yang memegang ijazah yang didasari dengan perjanjian yang disepakati oleh pekerja dan pengusaha. Hal ini berarti berpindahnya penguasaan terhadap benda berupa ijazah asli pekerja timbul karena adanya kesepakatan berupa perjanjian yang artinya ijazah tersebut sebagai jaminan agar pekerja tidak mudah untuk berhenti bekerja dengan pengusaha dan mencari pekerjaan di tempat lain. Berkenaan dengan perjanjian, R. Subekti menyatakan bahwa suatu perjanjian adalah suatu peristiwa dimana seseorang berjanji kepada orang lain atau dimana dua orang itu saling berjanji untuk melaksanakan sesuatu, dari peristiwa ini timbul hubungan perikatan (Harianto, 2016).
Proses terbentuknya perjanjian mengenai penahanan ijazah asli pekerja bermula dari sebelum adanya kesepakatan antara pekerja dengan pengusaha hingga pada pelaksanaan perjanjian. Mengacu pada teori, ada tiga tahap dalam membuat perjanjian yakni :

a. Tahap pracontractual, yaitu adanya penawaran dan penerimaan;

b. Tahap contractual, yaitu adanya persesuaian pernyataan kehendak antara para pihak;

c. Tahap post contractual, yaitu pelaksanaan perjanjian (HS, 2016).

Berdasarkan teori tersebut dikaitkan dengan penahanan ijazah asli milik pekerja, jelas bahwa tindakan tersebut bermula dari tahap pracontractual yakni saat pekerja melamar pekerjaan, ada proses penawaran dan penerimaan antara pekerja dan pengusaha berupa pekerja diterima bekerja oleh pengusaha dengan catatan ijazah asli milik pekerja tersebut ditahan untuk waktu yang ditetapkan oleh pengusaha. Pada tahap ini, jelas posisi pengusaha sebagai pemberi kerja lebih tinggi dari pekerja karena pekerja adalah pihak yang membutuhkan pekerjaan dan pengusaha adalah pihak yang menentukan diterima atau tidaknya pekerja untuk bekerja di perusahaannya. Terkait dengan penahanan ijazah ketika pekerja tidak sepakat dengan penahanan atas ijazah asli miliknya, maka konsekuensi yang terjadi adalah 
pekerja tidak diterima oleh pengusaha untuk bekerja di perusahaannya. Hal ini terjadi karena adanya ketidaksesuaian pendapat dalam penawaran dan penerimaan sehingga tidak bisa dianjutkan pada tahap selanjutnya.

Pada tahap selanjutnya yakni tahap contractual, pada tahap ini terkait dengan persesuaian pernyataan kehendak antara para pihak yakni kesepakatan pekerja dan pengusaha tentang diterimanya pekerja untuk bekerja oleh pengusaha dengan syarat ijazah asli milik pekerja tersebut ditahan oleh pengusaha sebagai jaminan dan dikembalikan pada waktu yang ditentukan. Pada tahap ini, kesepakatan terutama mengenai penahanan ijazah asli milik pekerja ini dapat dituangkan dalam bentuk perjanjian tertulis maupun tidak tertulis.

Perjanjian yang dibuat oleh para pihak dalam bentuk tertulis disertai dengan tanda tangan para pihak maka perjanjian tersebut memiliki kekuatan pembuktian yang kuat apabila terjadi permasalahan dalam penerapan perjanjian tersebut dibandingkan dengan perjanjian dalam bentuk tidak tertulis, namun pada umumnya terkait dengan kesepakatan penahanan ijazah asli pekerja ini diperjanjikan secara lisan antara para pihak. Pada dasarnya tidak ada masalah jika para pihak membuat perjanjian secara tertulis maupun tidak tertulis karena kebebasan pada pihak untuk membuat perjanjian tidak boleh dikekang.
Pada tahap yang terakhir yakni tahap post contractual, ini merupakan tahap pelaksanaan dari perjanjian yang telah disepakati oleh pekerja dan pengusaha terutama pelaksanaan penahanan ijazah asli milik pekerja. Pelaksanaan pada tahap terakhir ini dimulai dari penyerahan ijazah asli pekerja kepada pengusaha sebagai jaminan pekerja tidak menjadikan tempatnya bekerja sebagai batu loncatan maupun sebagai syarat agar mudah dalam mengurus pelatihan pekerja, hingga pada pengembalian ijazah asli tersebut secara utuh seperti dalam keadaan semula kepada pihak pekerja.

Perjanjian mengenai penahanan ijazah pekerja ini merupakan bagian dari asas kebebasan berkontrak. Salah satu pilar hukum perjanjian yakni asas kebebasan berkontrak yang secara universal dikenal oleh sistem hukum negara manapun, sebagai prinsip andalan yang mampu menjamin keleluasaan dan ketinggian intensitas kegiatan pasar. Kebebasan berkontrak yang berintikan keleluasaan dalam menentukan bentuk, jenis, dan isi perjanjian serasa tak akan lekang oleh tantangan zaman dan enggan lapuk akibat derasnya kemajuan. Prinsip ini memang merupakan salah satu bias sinar Hak Asasi Manusia yang selalu menjunjung tinggi harkat kehendak individu sebagai makhluk sosial (Isnaeni, 2013).

Kebebasan berkontrak pada dasarnya merupakan perwujudan dari kehendak bebas, pancaran hak 
$\begin{array}{lr}\text { asasi manusia } & \text { yang } \\ \text { perkembangannya } & \text { dilandasi } \\ \text { semangat liberalisme } & \text { yang } \\ \text { mengagungkan } & \text { kebebasan } \\ \text { individu (Hernoko, Op.Cit). }\end{array}$ Kebebasan berkontrak adalah asas yang esensial, baik bagi individu dalam mengembangkan diri baik di dalam kehidupan pribadi maupun kehidupan sosial kemasyarakatan, sehingga beberapa pakar menegaskan kebebasan berkontrak merupakan bagian dari hak asasi manusia yang harus dihormati (Harianto, op.cit).

Berkenaan dengan ruang lingkup asas kebebasan berkontrak, menurut Sutan Remi Sjahdeini asas kebebasan berkontrak menurut hukum perjanjian Indonesia meliputi ruang lingkup :

a. Kebebasan untuk membuat atau tidak membuat perjanjian.

b. Kebebasan untuk memilih pihak dengan siapa ia ingin membuat perjanjian.

c. Kebebasan untuk menentukan atau memilih kausa dari perjanjian yang akan dibuatnya.

d. Kebebasan untuk menentukan objek perjanjian.

e. Kebebasan untuk menentukan bentuk suatu perjanjian.

f. Kebebasan untuk menerima atau menyimpangi ketentuan undang-undang yang bersifat opsional (aanvullend, optional) (Hernoko;110).

Asas kebebasan berkontrak ini ditemui peraturannya dalam
Pasal 1338 ayat (1) Kitab UndangUndang Hukum Perdata yang menyatakan bahwa, "semua perjanjian yang dibuat secara sah berlaku sebagai undang-undang bagi mereka yang membuatnya." Ketentuan ini bermakna semua perjanjian yang dibuat oleh para pihak baik dalam bentuk dan jenis apapun, selama perjanjian tersebut dibuat secara sah maka isi dari perjanjian tersebut berlaku sebagai undang-undang bagi para pihak yang membuat perjanjian tersebut.

Untuk mengetahui perjanjian yang dibuat sudah secara sah atau tidak, dasar dari sahnya suatu perjanjian sebagaimana dalam pasal 1320 Kitab Undang-Undang Hukum Perdata harus memenuhi 4 (empat) syarat yakni :

1. Sepakat mereka yang mengikatkan dirinya;

2. Kecakapan untuk membuat suatu perikatan;

3. Suatu hal tertentu;

4. Suatu sebab yang diperbolehkan.

Pada syarat-syarat yang ditetapkan dalam pasal 1320 tersebut terbagi dalam dua kelompok yakni syarat subjektif dan syarat objektif. Syarat kesepakatan dan kecakapan termasuk dalam syarat subjektif sehingga apabila syarat subjektif ini tidak terpenuhi menimbulkan akibat hukum yakni perjanjian tersebut dapat dibatalkan. Syarat mengenai hal tertentu dan sebab yang diperbolehkan termasuk sebagai syarat objektif sehingga apabila syarat objektif ini tidak terpenuhi maka menimbulkan 
akibat hukum bahwa perjanjian tersebut batal demi hukum.

Berkenaan dengan perjanjian penahanan ijazah asli milik pekerja, terdapat proses dimulai dari mencari kesepakatan pihak pekerja dan pengusaha atas penahanan ijazah asli milik pekerja. Kesepakatan mengenai penahanan ijazah asli pekerja ini merupakan bagian yang paling penting menentukan terbentuk atau tidaknya suatu perjanjian. Untuk mencapai kesepakatan, para pihak memerlukan waktu untuk berpikir maupun berunding karena kesepakatan dalam perjanjian tersebut tidak boleh didasari adanya unsur paksaan terutama paksaan dari pengusaha. Kesepakatan yang timbul didasarkan dengan paksaan adalah contradictio interminis, sehingga dengan adanya paksaan sudah menunjukkan adanya ketidaksepahaman atau tidak sepakatnya salah satu pihak sehingga perjanjian tersebut dapat dibatalkan.

Perjanjian mengenai penahanan ijazah dalam hal keempat syarat yang telah dipenuhi dalam pasal 1320 Kitab Undang-Undang Hukum Perdata maka isi dari perjanjian yang telah disepakati dapat berlaku sebagai undang-undang bagi para pihak yang membuat perjanjian. Sebagaimana dalam asas privity of contract yang tertuang dalam Pasal 1340 Kitab Undang-Undang Hukum Perdata, karena yang dibuat oleh para pihak adalah perjanjian maka perjanjian tersebut hanya berlaku dan mengikat bagi para pihak yang membuat perjanjian tersebut.

Asas kebebasan berkontrak merupakan asas yang dapat digunakan dalam mengisi kekosongan hukum dalam hal jenis perjanjian atau substansi dari perjanjian tidak diatur dalam peraturan perundang-undangan, namun kebebasan menentukan substansi perjanjian itu harus pula memandang hak asasi manusia antara para pihak yang membuat perjanjian tersebut. oleh karena itu kebebasan berkontrak harus berdasarkan pada itikad baik dari masing-masing pihak yang membuat perjanjian sebagaimana dalam ketentuan Pasal 1338 ayat (3) Kitab Undang-Undang Hukum Perdata.

Perlu dimaknai bahwa kebebasan berkontrak ini bukan berarti bebas tanpa ada batasan. Mengacu pada ketentuan Pasal 1337 Kitab Undang-Undang Hukum Perdata yang menyatakan bahwa "suatu sebab adalah terlarang, apabila dilarang oleh undang-undang, atau apabila berlawanan dengan kesusilaan baik atau ketertiban umum" serta Pasal 1339 Kitab Undang-Undang Hukum Perdata yang menyatakan bahwa "suatu perjanjian tidak hanya mengikat untuk hal-hal yang dengan tegas dinyatakan didalamnya, tetapi juga untuk segala sesuatu yang menurut sifat perjanjian, diharuskan oleh kepatutan, kebiasaan atau undangundang". Berdasarkan pada ketentuan ini, maka yang dapat digunakan sebagai batasan dari kebebasan berkontrak adalah 
perjanjian tersebut tidak boleh bertentangan dengan UndangUndang, kesusilaan, ketertiban umum, kepatutan, dan kebiasaan. Mengingat asas kebebasan berkontrak lahir dari perwujudan hak asasi manusia, kebebasan berkontrak juga harus dibatasi dengan tidak boleh bertentangan dengan Hak Asasi Manusia dari salah satu atau para pihak yang membuat kontrak tersebut.

Asas kebebasan berkontrak dikaitkan dengan perjanjian kerja yang disepakati antara pekerja dan pengusaha merupakan kebebasan antara pihak pekerja dan pengusaha dalam membuat perjanjian terkait penahanan ijazah asli pekerja sebagai bentuk loyalitas pekerja bekerja di perusahaan. Asas kebebasan berkontrak sebagai dasar perjanjian penahanan ijazah asli milik pekerja tersebut tidak boleh bertentangan dengan UndangUndang, kesusilaan, ketertiban umum, kepatutan, dan kebiasaan. Kebiasaan perusahaan dalam melakukan penahanan ijazah berlaku sebagai hukum dalam perusahaan yang memperbolehkan terjadinya penahanan ijazah.

Peraturan Perundangundangan tidak melarang adanya penahanan ijazah, namun apabila dikaji dari segi Hak Asasi Manusia tindakan penahanan ijazah ini bertentangan dengan hak asasi manusia sebagaimana dalam pasal 27 ayat (2) Undang-Undang Dasar bahwa tindakan pengusaha melakukan penahanan ijazah asli ini menghalangi hak pekerja untuk mendapat pekerjaan yang mampu memberikan penghasilan yang lebih layak. Atas tindakan penahanan ijazah asli milik pekerja, maka hak pekerja untuk mencari penghasilan yang layak demi memenuhi kebutuhan kehidupannya seolah-olah diperkosa oleh pengusaha. Semestinya pengusaha tidak perlu untuk melakukan penahanan ijazah, sebagaimana dalam ketentuan Pasal 62 UndangUndang Republik Indonesia Nomor 13 Tahun 2003, jika pihak pekerja yang mengakhiri hubungan kerja sebelum waktu berakhirnya jangka waktu yang ditetapkan, maka pekerja tersebut wajib membayar ganti rugi kepada pengusaha.

Mengingat

tindakan penahanan ijazah bertentangan dengan hak asasi manusia, maka untuk memberikan perlindungan terhadap Hak Asasi Manusia atas hak atas pekerjaan dan penghidupan yang layak, maka pemerintah diharapkan membentuk peraturan terkait dengan penahanan ijazah asli pekerja sehingga peraturan ini dapat digunakan sebagai dasar atau bagian dalam kebebasan berkontrak.

\section{Simpulan}

Penahanan ijazah asli milik pekerja jika dilihat dari sumber hukum yang ada maka dalam peraturan perundang-undangan terkait ketenagakerjaan terdapat kekosongan hukum terkait hal ini. Atas kekosongan hukum yang terjadi, pengusaha melakukan tindakan penahanan ijazah dengan 
berdasarkan pada kebiasaan serta perjanjian sebagai sumber hukumnya.

Kesepakatan mengenai penahanan ijazah asli milik pekerja yang dituangkan dalam perjanjian merupakan bagian dari asas kebebasan berkontrak, namun kebebasan ini bukan berarti bebas tanpa batas. Pada peraturan perundang-undangan memang tidak dijumpai pengaturan terkait penahanan ijazah asli pekerja, namun dari segi Hak Asasi Manusia, tindakan pengusaha dianggap menghalang-halangi pekerjanya sebagai manusia dalam mencari penghasilan yang dapat menunjang penghidupannya secara layak.

\section{Saran}

Tindakan penahanan ijazah perlu mendapat pengaturan yang lebih jelas dalam peraturan perundang-undangan terkait, sehingga diharapkan peran pemerintah untuk membentuk peraturan perundang-undangan yang mengatur terkait penahanan ijazah asli pekerja demi melindungi hak asasi manusia dari pihak pekerja.

\section{Daftar Pustaka}

Buku

Asikin, H. Zainal, et. al. 2008, Dasar-Dasar Hukum Perburuhan, Rajagrafindo Persada, Jakarta.

Erwin, Muhamad, 2013, Filsafat Hukum : Refleksi Kritis terhadap Hukum, Rajawali Pers, Jakarta.

Harianto, Aries, 2016, Hukum Ketenagakerjaan; Makna Kesusilaan dalam Perjanjian Kerja, Laksbang Pressindo, Yogyakarta.

Hernoko, Agus Yudha, 2010, Hukum Perkanjian Asas Proporsionalitas Dalam Kontrak Komersial, Kencana, Jakarta.

Isnaeni, H. Moch., 2013, Perkembangan Hukum Perdata Di Indonesia, Laksbang Grafiika, Yogyakarta.

Khakim, Abdul, 2014, Dasar-Dasar Hukum Ketenagakerjaan Indonesia, Citra Aditya Bakti, Bandung.

Ramli, Lanny, 2008, Hukum Ketenagakerjaan, Airlangga University Press, Surabaya.

Salim, HS, 2016, Pengantar Hukum Perdata Tertulis (BW), Sinar Grafika, Jakarta.

\section{Undang-Undang}

Undang-Undang Dasar Negara Republik Indonesia Tahun 1945.

Kitab Undang-Undang Hukum Perdata.

Undang-Undang Republik Indonesia Nomor 13 Tahun 2003 Tentang Ketenagakerjaan (Lembaran Negara Republik Indonesia No.39, 2003, Tambahan Lembaran Negara Republik Indonesia No. 4279). 